\title{
THE INVOLVEMENT OF A FERROUS PROTEIN COMPLEX IN THE NATURAL ADRENALINE RECEPTOR
}

\author{
REIJI IMAIZUMI ANI IIIROSHI YOSHIDA \\ Department of Pharmacology, Oxaka Unizcrity Melical School, Osaka \\ Received for publication February 22, 1961
}

There have been many reports on the adrenaline receptor by many workers such as Dale (1), Ahlquist (2), Lands (3), Furchgott (4), and Ellis (5). In these reports various kinds of adrenaline receptors have been distinguished and given different names. However, such classification have been made only on the basis of differences in the response of the various organs to sympathomimetic and sympatholytic drugs with different chemical structures. Little is known about the nature of the receptor itself.

A series of papers on the acetylcholine receptor by Nachmansohn's group $(6,7)$ and the papers by Woolley $(8,9)$ on the serotonin receptor are of interest in connection with the nature of the receptor itself.

In this paper, the peculiar effect of ferrous ion on the vasoconstrictive action of adrenaline and on the binding of adrenaline with protein are described, and it is suggested that the adrenaline receptor may be a ferrous protein complex.

\section{Infuence of Ferrous Ion on the Vasoconstrictive Action of Adrenaline}

Method: The perfusion method of rabbit ear vessels by Krawkow-Pissemski was used. Two Mariotte bottles, one of which contained normal Locke-Ringer solution and the other $10^{-8} \mathrm{M} \alpha \alpha^{\prime}$-dipyridyl or o-phenanthroline containing Locke-Ringer solution, were prepared so that the perfusate could be changed at any time.

Results and Discussion: As shown in Fig. 1, the following four phenomena were observed with time.

1) Potentiation of adrenaline action by perfusion of the chelating agents.

2) The adrenaline action disappeared after long term perfusion of these agents.

3) The adrenaline action reappeared on infusion with a small amount of ferrous ion after the treatment with chelating agents.

4) The adrenaline action disappeared again after infusion with a large amount of ferrous ion.

Of the above four phenomena, I) and 4) may be explained by the inhibitory effect of metal ions, including ferrous ion, on the adrenaline action as has been reported already by many workers $(1012)$. However, it does not seem possible to explain the fact that the action of adrenaline almost disappeared after long perfusion with $\alpha \alpha^{\prime}$-dipyridyl or $o$-phenanthroline on this basis. At this stage, the action of barium chloride was unaffected, 
so that the mechanism of vasoconstriction itself does not seem to have been damaged. One of the specific factors which regulates the strength of drug action is the activities of the enzymes which destroy the drug. The main mechanism by which adrenaline is inactivated in blood vessels is supposed to be o-methyl transferase. But it seems unlikely that the activity of this enzyme increases greatly on infusion of a small volume of ferrous ion (13). Another possible explanation is that the receptor of adrenaline has ferrous ion in its active site and combines with adrenaline through a ferrous ion as linkage. If so, the disappearance of the adrenaline action by perfusion with chelating agents such as $\alpha \alpha^{\prime}$-dipyridyl and $\sigma$-phenanthroline and the reappearance of its activity on infusion of a small volume of ferrous ion could be reasonably explained. Furthermore, the inhibition of the adrenaline action by excessive amount of ferrous ion may be explained by considering that a stable adrenaline-ferrous complex is formed, as discussed in the next section. At the earlier stage of perfusion with chelating agents, ferrous ions in their free form might be removed with other heavy metals and the action of adrenaline be strengthened. However at the later stage the ferrous ion of adrenaline receptor might also be removed by the chelators so that the action of adrenaline is lost.

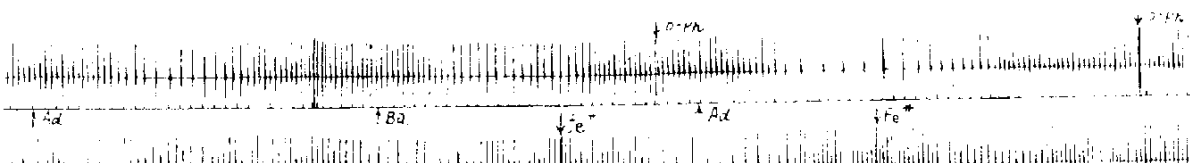

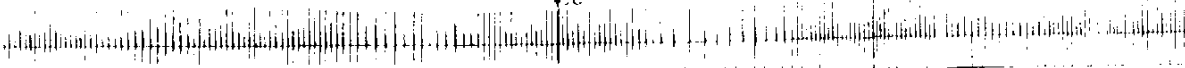

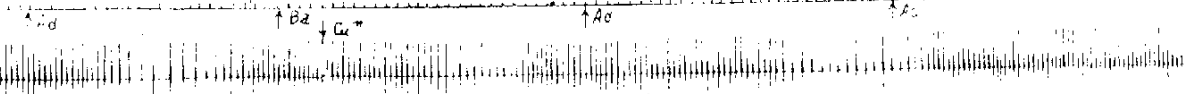
$\because 2$

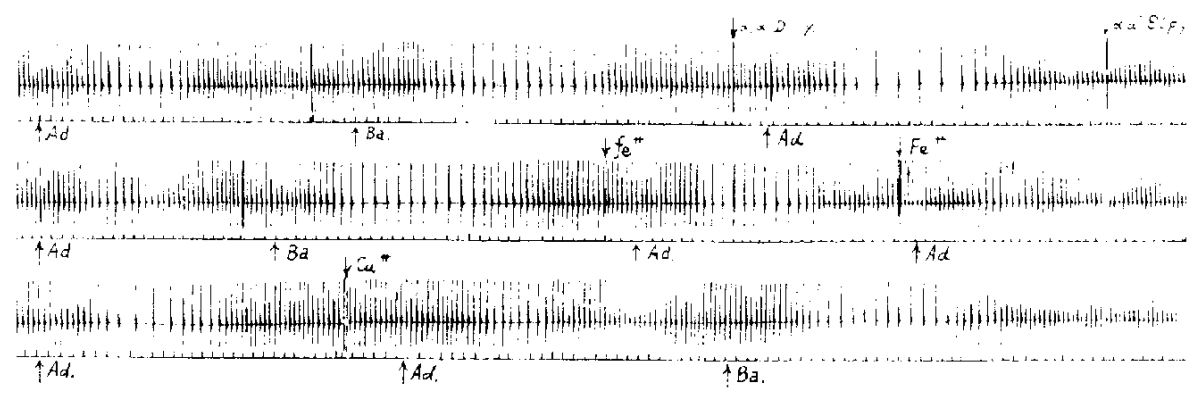

Fig. 1 A \& B. Effect of ferrous ion on the vasoconstrictive action of adrenaline (Pissemski's method).

Ad : $0.5 \mathrm{ml}$ of $10^{-7} \mathrm{~g} / \mathrm{ml}$ adrenaline

$\mathrm{Ba}: 0.5 \mathrm{ml}$ of $10^{-1} \mathrm{~g} / \mathrm{ml}$ barium chloride

o-ph. : 1 or $2 L$ of $\mathrm{M} / 1000$ o-phenanthroline in normal Locke-Ringer solution was perfused.

$\mathrm{fe}^{++}: 0.5 \mathrm{ml}$ of $\mathrm{M} / 5000 \mathrm{FeCl}_{2}$

$\mathrm{Fe}^{++}: 0.5 \mathrm{ml}$ of $\mathrm{M} / 500 \mathrm{FeCl}_{2}$

$\mathrm{Cu}^{++}: 0.5 \mathrm{ml}$ of $\mathrm{M} / 5000 \mathrm{CuCl}_{2}$

a $\alpha^{\prime}$-Dipy. : 1 or $2 L$ of $\mathrm{M} / 1000$ á'-dipyridyl in normal Locke-Ringer solution was perfused. 


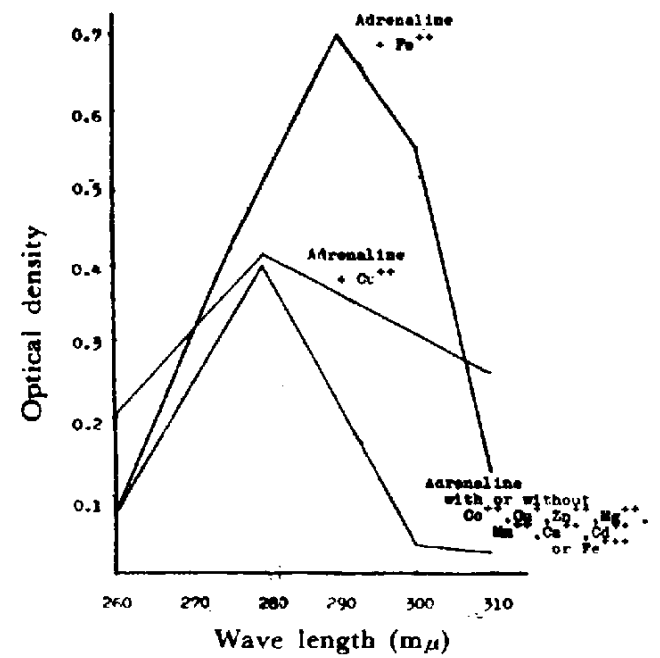

FiG. 2. Ultraviolet spectrum of adrenaline with and without jons.

One milliliter of adrenaline $(0.5 \mathrm{~mm})$, $1 \mathrm{ml}$ of salt solution $(0.25 \mathrm{mM})$ and $2 \mathrm{ml}$ of veronal buffer $(M / 30, F H 7.3)$ were mixed and examined.

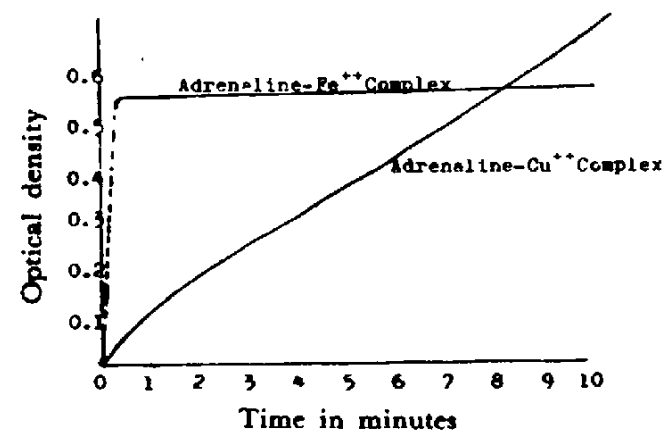

Fic. 3. Time course of the formation of the adrenaline-Fe ${ }^{++}$and adrenaline-Cu${ }^{++}$ complexes.

Reaction mixture : 2 ml of adrenalin ( $1 \mathrm{mM}$ ), $1 \mathrm{ml}$ of $\mathrm{FeCl}_{3}$ or $\mathrm{CuCl}_{2}$ (1 $\mathrm{mM}$ ) and $4 \mathrm{ml}$ of veronal buffer (M) 30, $\mathrm{pH} 7.3$ )

The reaction was measured at $560 \mathrm{~m} \mu$ for the adrenaline-Fe ${ }^{++}$complex and at $450 \mathrm{~m} \mu$ for the adrenaline-Cu${ }^{4+}$ complex.

\section{Formation of an Adrenaline-Ferrous Complex}

1) Change in the ultraviolet spectrum of adrenaline on addition of ferrous ion

The ultraviolet spectra of adrenaline with ions such as $\mathrm{Fe}^{++}, \mathrm{Fe}^{+++}, \mathrm{Cu}^{+}, \mathrm{Cu}^{++}$, $\mathrm{Mg}^{++}, \mathrm{Mn}^{++}, \mathrm{Ca}^{++}, \mathrm{Co}^{++}$, and $\mathrm{Zn}^{++}$, were examined in a Beckman spectrophotometer. As shown in Fig. 2, the maximum absorption of adrenaline shifted from $280 \mathrm{~m} \mu$ to $290 \mathrm{~m} \mu$ on addition of ferrous ion, but other metal ions did not greatly affect its spectrum.

2) Appearance of color on mixing calechol derivatives with metal ions

The dihydroxyphenyl derivatives, adrenaline, noradrenaline, noradrenalone, hydroxytyramine and protocatechuic acid, gave an intense violet blue color with ferrous ion, but adrenalone gave a reddish violet color. Compounds other than dihydroxyphenol derivatives, such as 3,4-dimethylglyoxalate, 3,4-dimethoxybenzaldehyde and sympatol did not give any color with ferrous ion. Of the many metal ions tested, a stable coloration with adrenaline was only given by ferrous ion. Its absorption peak was found at $560 \mathrm{~m} \mu$. A reddish color with an absorption peak at about $\mathbf{4 5 0}$ $\mathrm{m} \mu$, developed gradually on addition of certain ions such as the cupric ion may have been caused by their stimulation of the oxidation of adrenaline to adrenochrome.

3) Optimal $\mathrm{pH}$ for the formation of the adrenaline-ferrous complex

The optimal $\mathrm{pH}$ was at 7.3 , as shown, in Fig. 4.

\section{4) Molar ratio of adrenaline to ferrous in the complex}

The ratio was measured by the continuous variation method of Job (14). It was. found that 2 moles of adrenaline combine with 1 mole of ferrous ion. 


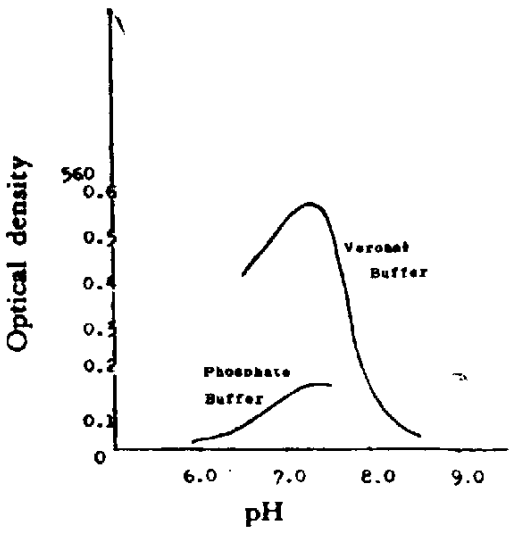

Fig. 4. Optimal pH for the formation of the adrenaline-ferrous complex.

Reaction mixture: $2 \mathrm{ml}$ of adrenaline (1 $\mathrm{mm}), 1 \mathrm{ml}$ of $\mathrm{FeCl}_{2}(1 \mathrm{mM})$ and $4 \mathrm{ml}$ of veronal buffer (M/30, pH 6.0 9.0) or phosphate buffer ( $M / 30, \mathrm{pH} 6.0$.7.5)

Measurements were made at $560 \mathrm{~m} \mu$ in a Coleman spectrophotometer.

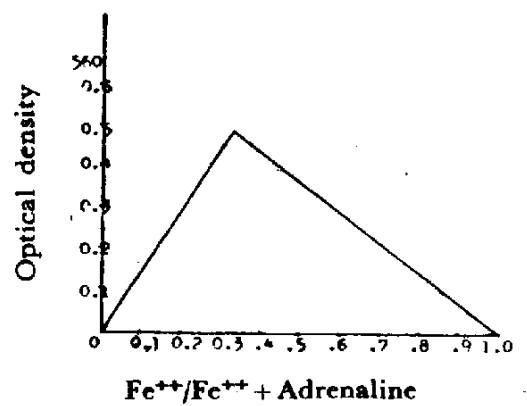

FIG. 5. Molar ratio of adrenaline to ferrous ion in the complex.

Adrenaline solution ( $1 \mathrm{~mm}$ ) and $\mathrm{Fe}^{++}$solution (1 mM) were mixed in varying proportions, maintaining the total volume at $2 \mathrm{ml}$.

Three milliliters of veronal buffer (M/30, pH 7.3) was added to above mixture and the optical densities was measured at 560 $\mathbf{m} \boldsymbol{\mu}$.

\section{5) Drop in $p H$ on formation of the adrenaline-ferrous complex}

The $\mathrm{pH}$ of the adrenaline and ferrous chloride solutions were adjusted to exactly 7.0 with a $\mathrm{pH}$ meter. The two solutions were mixed at a molar ratio of $2: 1$ and the $\mathrm{pH}$ of the mixture was measured. There was a large decrease in $\mathrm{pH}$ from 7.0 to 4.5 . The liberation of hydrogen ions on mixing the adrenaline with ferrous ion solutions was measured manometrically in a bicarbonate medium. It was found that one hydrogen ion was liberated per molecule of adrenaline.

From the above results, it is assumed that two moles of adrenaline lose their two hydrogen ions and form a stable complex with one ferrous ion. The formula to this compound is suggested to be shown in Fig. 6.

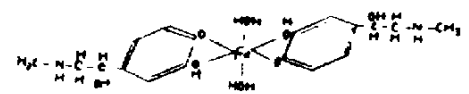

FIG. 6. Proposed formula of the adrenaline-ferrous complex.

\section{The Binding between the Adrenaline and the Ferroprotein}

Form the results shown in Section $I$, it is proposed that the receptor of adrenaline in the blood vessel which causes vasoconstriction is a ferroprotein complex. Therefore, in this section experiments on the possibility that adrenaline is bound to protein through ferrous ion linkage are described. Rabbit heart was used as the protein, because the heart is one of the most susceptible organs to adrenaline. 


\section{Preparations and methods}

Preparation of protein: Three grams of rabbit heart were immersed in Ringer solution to wash out the blood and then cut into small pieces with scissors and homogenized in $50 \mathrm{ml}$ of $0.9 \% \mathrm{KCl}$. The homogenate was disrupted in a sonic oscillator for $30 \mathrm{~min}$ at $60 \mathrm{~V}$ and $9 \mathrm{kc}$. Then the material was centrifuged at $54,000 \times \mathrm{g}$ for $30 \mathrm{~min}$ and the soluble fraction was used in following experiments. All procedures were carried at $0^{\circ}-4^{\circ} \mathrm{C}$. Preparation of ferroprotein

Four milliliters of the protein solution described above were diluted with same volume of veronal buffer $\left(5 \times 10^{-\mathrm{x}} \mathrm{M} \mathrm{pH} 7.3\right)$ and then $1 \mathrm{ml}$ of ammonium ferrosulfate $\left(0.25 \times 10^{-8}\right.$ $M)$ in ascorbic acid solution $\left(0.25 \times 10^{-3} \mathrm{M}\right)$ was added. The mixture was stood for $30 \mathrm{~min}$ and then brought to $80 \%$ saturation with ammonium sulfate, maintaining the $\mathrm{pH}$ of the mixture at neutrality. The mixture was then centrifuged at $1,500 \times g$ for $30 \mathrm{~min}$. The resulting precipitate was used as ferrous protein.

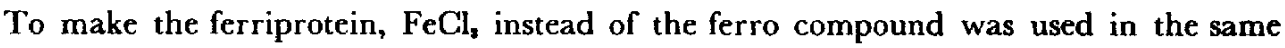
procedure.

Equilibrium dialysis: The reaction mixture shown in Table 1 was put on both sides of the cellophane membrane in the apparatus shown in Fig. 7. The air in the apparatus was displaced by nitrogen. The apparatus was shaked in a cold room for 24 hours to equilibrate.

Determination of adrenaline and protein: Adrenaline was estimated by Euler's method (15). When protein was present, 4 volumes of $95 \%$ ethanol containing $2.5 \% \mathrm{v} / \mathrm{v}$ of $1 \mathrm{~N}-$ $\mathrm{H}_{2} \mathrm{SO}_{4}$ were added to the sample to precipitate the protein. The supernatant was then condensed at reduced pressure at about $40^{\circ} \mathrm{C}$. Then its adrenaline content was estimated.

The amount of protein in the reaction mixture was calculated from the following formula of Kalcker (16).

$$
\text { Protein concentration }(\mathrm{mg} / \mathrm{ml})=1.45 \mathrm{D}_{200}-0.74 \mathrm{D}_{200}
$$

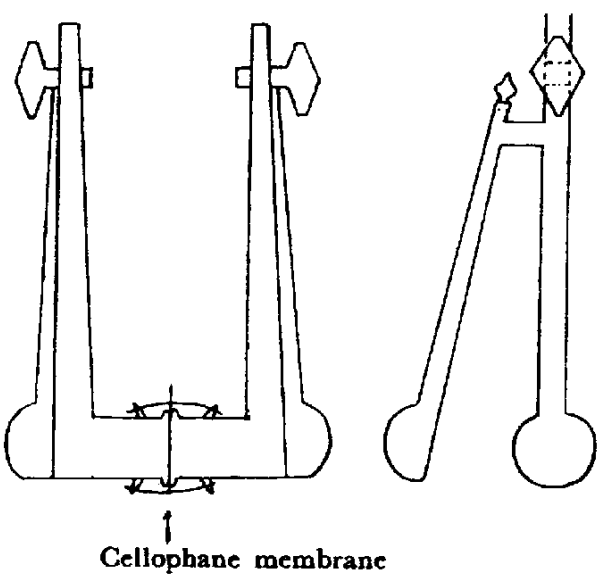

FIG. 7. Apparatus used for equilibrium dialysis.
TABLE 1. Binding of protein, ferroprotein and ferriprotein with adrenaline.

\begin{tabular}{lll}
\hline & \multicolumn{2}{l}{ Adrenaline concentration } \\
& Buffer side & Protein side \\
\hline Buffer + Adrenaline & $1.0 \times 10^{-\mathrm{M}}$ & $1.0 \times 10^{-5} \mathrm{M}$ \\
Protein + Adrenaline & 0.98 & 1.02 \\
Ferroprotein + Adrenaline & 0.81 & 1.15 \\
Ferriprotein + Adrenaline & 0.94 & 0.98 \\
\hline
\end{tabular}

One side : $2 \mathrm{ml}$ of adrenaline $\left(2.5 \times 10^{-3} \mathrm{M}\right)$ and $3 \mathrm{ml}$ of veronal buffer $\left(5 \times 10^{-8} \mathrm{M}, \mathrm{pH} 7.0\right)$

The other side : $2 \mathrm{ml}$ of adrenaline $\left(2.5 \times 10^{-5} \mathrm{M}\right)$ and 3 $\mathrm{ml}$ of buffer or protein solution dissolved in the same buffer 
Results

1) The binding ability of protein, ferroprotein and ferriprotein with adrenaline

Table 1 shows that ferroprotein binds adrenaline, while protein and ferriprotein do not. Ferriprotein reduced the adrenaline content in the buffer side of the apparatus but the concentration in the protein solution did not increased. Therefore adrenaline may oxidized by the presence of ferriprotein, even under our experimental conditions.

2) The influence of $p H$ on the binding of adrenaline to ferroprotein

Veronal buffer of different $\mathrm{pH}$ values ( $\mathrm{pH} 7.0,6.0$ and 5.0$)$ was used in this experiment. No alkaline medium was tested because it was impossible to avoid autoxidation of adrenaline in alkali. The ability of ferroprotein to bind adrenaline was estimated from the amount of adrenaline in the buffer dialysed against the protein solution. As shown in Table 2, the ability of ferroprotein to bind adrenaline seemed to decrease with the $\mathrm{pH}$ of the medium. It is interesting to consider this result in relation with the fact that the vasoconstrictive action of adrenaline is suppressed by acidity.

TABLE 2. Influence of $\mathbf{p H}$ on the binding of adrenaline with ferroprotein.

\begin{tabular}{lc}
\hline & $\begin{array}{c}\text { Adrenaline concentration } \\
\text { in buffer side }\end{array}$ \\
\hline Adrenaline + Buffer (pH 7.0) & $1.0 \times 10^{-\mathrm{s}} \mathrm{M}$ \\
Adrenaline + Ferroprotein (pH 7.0) & 0.81 \\
Adrenaline + Ferroprotein (pH 6.0) & 0.87 \\
Adrenaline + Ferroprotein (pH 5.0) & 0.91 \\
\hline
\end{tabular}

Experimental conditions as described in the text and Table 1.

3) Comparison of the ability of different protein fractions to bind adrenaline

The experiments described above showed that protein may combine with adrenaline through ferrous ion. However it is uncertain whether all proteins have the same affinity for adrenaline or whether only some specific proteins can bind it. To test this the protein extracted from rabbit heart was fractionated into four fractions with ammonium sulfate. These fractions were those precipitating at $0-20 \%, 20-40 \%, 40-60 \%$ and $60-80 \%$ saturation of ammonium sulfate. Each fraction was treated with ferrous ion according to the method described above, and their ability to combine with adrenaline was measured by the equilibrium dialysis method.

TABle 3. Binding of adrenaline with protein fractions from heart.

\begin{tabular}{lll}
\hline \multicolumn{1}{c}{ Protein fraction } & $\begin{array}{c}\text { Concentration of } \\
\text { adrenaline in } \\
\text { buffer side }\end{array}$ & $\begin{array}{c}\text { Amount of } \\
\text { bound adrenaline } \\
(\mathrm{\mu g} / \mathrm{mg} \text { protein) }\end{array}$ \\
\hline Buffer + Adrenaline & $1.0 \times 10^{-5} \mathrm{M}$ & \\
$0-20 \%$ fraction + Adrenaline & 0.915 & 1.2 \\
$20-40 \%$ fraction + Adrenaline & 0.942 & 0.16 \\
40-60\% fraction + Adrenaline & 0.913 & 0.40 \\
$60-60 \%$ fraction + Adrenaline & 0.886 & 0.96 \\
\hline
\end{tabular}


As shown in Table 3, two fractions had a high affinity for adrenaline. These were the fractions precipitating at $0-20 \%$ and $60-80 \%$ saturation of ammonium sulfate.

\section{4) Effects of structural analogues of adrenaline on the binding of ferroprotein with adrenaline}

If pretreatment of ferroprotein with structural analogues of adrenaline inhibited the binding of ferroprotein with adrenaline and if the degree of this inhibition depended on chemical structure of the analogues, it would throw some light on the type of linkage of the ferroprotein and adrenaline. Furthermore, since two different proteins seemed to be able to bind adrenaline, these might behave differently with the analogues. Therefore the following experiments were carried out.

The fractions precipitating at $0-20 \%$ and $60-80 \%$ saturation of ammonium sulfate were used in this experiment after treatment with ferrous ion.

TABI.E 4. Effect of structural analogues of adrenaline on the binding of adrenaline with ferroprotein.

\begin{tabular}{|c|c|c|}
\hline \multirow{2}{*}{ Analogue } & \multicolumn{2}{|c|}{ Percentage of inhibition } \\
\hline & Albumin fraction & Globulin fraction \\
\hline Ephedrine & 20 & 30 \\
\hline Methylaminoethanol & 11 & 13 \\
\hline 3-Hydroxytyramine & 10 & 11 \\
\hline Sympatol & 20 & 13 \\
\hline Tyramine & 22 & 16 \\
\hline Adrenalone & 93 & 70 \\
\hline Noradrenalone & 63 & 41 \\
\hline
\end{tabular}

Three milliliters of analogue solution $\left(2.5 \times 10^{-2} \mathrm{M}\right)$ were added to $4 \mathrm{ml}$ of ferroprotein solution and after standing the mixture for $10 \mathrm{~min}$.

Three milliliters of the mixture were used in the apparatus as the protein sample.

The results obtained are shown in Table 4. All the adrenaline analogues tested inhibited the binding of protein to adrenaline. Therefore it seems that three groups are important in determining the strength of binding: $\beta$-carbon with oxygen, the methyl group attached to nitrogen and the dihydroxyphenyl group. This results is in agreement with speculations on adrenaline receptors already proposed in various papers. There was no difference between in the behavior of the two protein fractions with these structural analogues.

5) Combination of protein from various organs with adrenaline

Protein was extracted from the rabbit heart, intestine, serum, brain and liver by the method described above. These were fractionated with ammonium sulfate and treated with ferrous ion. Then, their ability to bind adrenaline was measured by the equilibrium method.

As shown in Table 5, the ability to bind adrenaline was not present to the same degree in all the fractions of each organs. Moreover the protein which combined with 
Tard, 5. Binding of adrenaline by protein fractions from various organs.

\begin{tabular}{cccccc}
\hline $\begin{array}{c}\text { Ammonium sulfate } \\
\text { fraction }\end{array}$ & \multicolumn{4}{c}{ Bound adrenaline ( $\mathrm{Hg} / \mathrm{mg}$ protein) } \\
\hline $0-20 \%$ & 1.2 & 4.92 & 1.2 & 0.22 & 2.96 \\
$20-40 \%$ & 0.16 & 1.47 & 0.01 & 0.01 & 0.67 \\
$40-60 \%$ & 0.4 & 2.35 & 0.06 & 0.04 & 2.31 \\
$60-80 \%$ & 0.96 & 3.45 & 0.12 & 0.07 & 0.64 \\
\hline
\end{tabular}

adrenaline was not present in the same fractions in the different organs. Thus in the heart, serum and liver there was the same distribution of active protein. However in the brain the active protein was present in fractions precipitating at $0-20 \%$ and $40-60 \%$ saturation of ammonium sulfate.

\section{DISCUSSION}

Of many ions tested adrenaline combines most readily with ferrous ion forming a chelating compound at a molar ratio of $2: 1$, as shown in Section II. The formation of this chelating compound with ferrous ion was observed not only with adrenaline but also with many other o-dihydroxyphenyl derivatives. Therefore, the binding may be between the o-dihydroxyphenyl group and the ferrous ion. Moreover, in Section III, experiments on the binding of adrenaline with protein are described and it is shown that adrenaline combines with the protein of various organs through a ferrous linkage. From the experiments with structural analogues of adrenaline, a $\beta$-carbon linked to oxygen and a nitrogen attached to a methyl group are also seemed to be important factors for the binding (Fig. 8). Since the ability of ferroprotein to bind adrenaline decreased with acidity, the ferrous linkage is more sensitive than the positive charge of the side chain nitrogen of adrenaline to change in $\mathrm{pH}$. Although our results show that a certain protein can combine with adrenaline, the nature of this protein is unknown.

Physiologically it is known that there are two kinds of binding of adrenaline by large molecular substances, including protein, in vivo.

Adrenaline can either combine with a receptor related to the appearance of its action or with a certain protein resulting in a formation of inactive bound form of adrenaline. The receptor related to its function is secmed to be only observed in highly organized system as far as complicated functions such as vasoconstriction are concerned. However it seems unlikely to take up such a

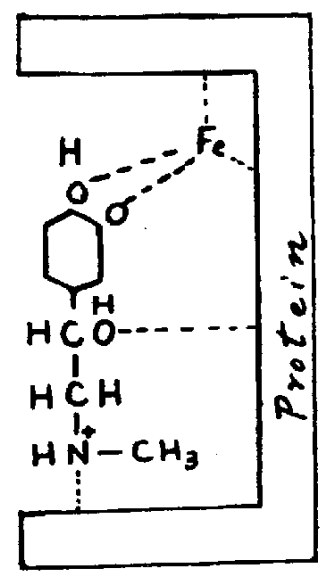

Fig. 8. Hypothetical mode of binding of adrenaline and protein. complicated system to study the nature of the receptor itself. Therefore, the complicated system must be disrupted for this purpose. But, when an organized system is disrupted the function of the receptor is lost and it is very hard to distinguish the true receptors 
from protein which can combine with adrenaline but has no relation to the function. Considering such complicated problems, we carried out our experiments.

By the long term perfusion with $\alpha \alpha$-dipyridyl or $\sigma$-phenanthroline the action of adrenaline was diminished but recovered on infusion of a small amount of ferrous ion. These results together with those shown in Section II and III suggest that the adrenaline receptor may be a ferroprotein. The binding of adrenaline by ferroprotein was inhibited by acidity. This is of interest, because it is already known that the vasoconstrictive action of adrenaline is suppressed in acidic media. The finding that the o-dihydroxyphenyl, the $\beta$-carbon coupled to oxygen and the nitrogen atom linked to methyl group are important factors in the binding of adrenaline with ferroprotein is in good agreement with the well known fact that these three are the most essential for the action of adrenaline.

Thus it is postulated that the adrenaline receptor is a ferroprotein. If the adrenaline receptor is indeed a ferroprotein, the potentiation of the vasoconstrictive action of adrenaline by hydroquinone (19), ascorbic acid (18) and cysteine may be explained by the ability of these compounds to reduce the inactive receptor ferriprotein to the active receptor, ferroprotein.

\section{SUMMARY}

1. On perfusion of $\alpha \alpha^{\prime}$-dipyridyl or o-phenanthroline through the vessels of the rabbit's ear, the vasocontrictive action of adrenaline was diminished. Its activity was recovered by infusion of a small amount of ferrous ion through the preparation. From these results the presence of ferrous ion was judged to be necessary for the action of adrenaline.

2. Adrenaline forms a chelate compound with ferrous ion with a molar ratio of $2: 1$.

3. Adrenaline was bound by the protein of various organs in the presence of the ferrous ion. The binding of adrenaline by ferroprotein was inhibited by structural analogues of adrenaline and by acidity.

4. The type of binding of adrenaline with protein is discussed on the basis of the results and a ferroprotein is proposed to be the natural receptor of adrenaline.

\section{REFERENCES}

1) Dale, H. : J. Physid. 34, 163 (1906)

2) AHLQUIST, R.P. : Amer. J. Physid. 153, 586 (1948)

3) La.vds, A.M. : Pharmacol. Rev. 1, 279 (1948) ; Amer. J. Physial. 169, 11 (1952)

4) FurchgotT, R.F. : Pharmacd. Reo. 11, 429 (1959)

5) EuLJs, S. : J. Pharmacol. 101, 92 (1951)

6) Nachmansohn, D. : Chemical and Molecular Basis of Neroe Activity, Academic Press, New York (1959)

7) Ehrenpreis, S. : Biochin. Biophos. Acta 44, 561 (1960)

8) WoOlley, D.W. : Prac. Nall. Acad. Sci, U.S. 44, 197 (1958) ; 4, 1202 (1958)

9) Woolley, D.W. and Campbell, N.K. : Biochin. Biophys. Aeta 40, 543 (1960)

10) Straub, W. and Stefansson, K. : Arch. exp. Palh. Pharmak. 194, 269 (1940) 
11) Kesztyus, L., Szalagyi, T. and Varca, E. : Cited from Ber. ges. Physiol. 198, 247 (1949)

12) ANDO, J. : Bull. Osaka Med. Sch. 1, 26 (1954)

13) AXeriod, J. AND Tomchick, R. : J. biol. Chem. 233, 702 (1958)

14) Martelu, A.E. ANd Galvin, M. : Chemidry of the Metal Chelate Compounds P.29 (1952)

15) EULER, U.S. vON AND Floding, I. : Acta physid. seand. 33, Suppl. 118, 57 (1955)

16) Kalcker, H.M. : J. biol. Chem. 167, 461 (1947)

17) URano, K. : Folia pharmacod. japon. 44, 77\$ (1949)

18) Imaizumi, R. and Yoshida, H. : Med. J. Osaka Univ. 1, 115 (1953)

19) YoshidA, H. AND NODA, T. : Osaka Daigaka Igakes Zaschi 6, 193 (1954) 